\title{
Police Drones: A Legal Studies Case Study
}

Benjamin A. Neil, Towson University, USA

Benjamin A. Neil II, Homeland Security and Towson University, USA

\begin{abstract}
This case offers the students the opportunity to apply their knowledge of the Fourth Amendment of the United States Constitution, as it applies to the concept of unreasonable search and seizure. With this particular case problem being based on the recent action involving the defendant, Rodney Brossart and the State of North Dakota, wherein an unmanned military grade drone was used by the local police department, for the first time in the United States, to affect an arrest.
\end{abstract}

Keywords: Fourth Amendment; Search and Seizure; Warrantless Search; Reasonable Expectation of Privacy; Cartilage

\section{INTRODUCTION}

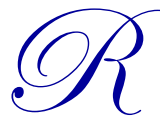

odney Brossart's saga began in June, 2011 when the North Dakota police decided to call in an unmanned Predator surveillance drone. As a dispute had arisen concerning allegations of cattle theft, when six cows wandered onto his 3,000 acre farm. He believed that he should be able to keep the cows, so he and two family members chased police off his land with high powered rifles.

Ultimately, a military grade department of Homeland security owned drone was deployed and a local SWAT team called in armed with a search warrant. The SWAT team moved in and arrested Brossart; making him the first American to be arrested with the assistance of a drone.

The Los Angeles Times characterized the incident as "the first known arrest of U.S. citizens with the help from a Predator, the spy drone that has helped revolutionize modern warfare." According to the same repost, North Dakota police say they have used unarmed Predators based in Grand Forks for two dozen surveillance flights between June 2011 and December 2011.

Until now, there has been next to no political or legal debate about whether it's actually a good idea to use drones for domestic law enforcement purposes. Air Force officials justify their actions by citing congressional budget requests that include "interior law enforcement support: as part of their mission.

In response to the L.A. Times report, Salon's Glenn Greenwald argued that the use of drones to arrest U.S. citizens at home is an ominous development enabling "a surveillance state unlike anything we've ever seen".

He continued. "No matter one's views, the escalating addition of drones - weaponized or even just surveillance - to the vast arsenal of domestic weapons that already exist is a serious, consequential development. The fact that it has happened with almost no debate and no legal authorization is itself highly significant. One thing is for certain: this is a development that is going to continue and increase rapidly. It needs far more attention than it has thus far received.

Brossart now challenges that arrest, as a violation of the Fourth Amendment to the United States Constitution, among other arguments.

\section{PREMISE}

In June, 2011 six cows wandered onto land owned by Rodney Brossart, who declined to return them to their owner until he was paid for the feed the cattle consumed. As such, he believed he should have been able to keep the cows. 
The local police ultimately got involved and when they went to the property, they were met by Brossart and two of his family members who chased the police off his land with high powered rifles. As a result, there was a 16 hour standoff that ensued with Brossart and others on the property, which ended with the local police department getting a search warrant for the property.

The police department SWAT team, now armed with the search warrant, used an existing agreement with the Federal Department of Homeland Security, which owned a military grade Predator surveillance drone. It was able to pinpoint Brossart's location on the ranch. According to Bill Macki, head of the Grand Forks SWAT team, "the terrain we were working with was very large and agricultural - several hundred acres of flat farmland made it difficult to set up a perimeter to ensure people didn't make it off the property. I think the drones are definitely a useful tool, their effectiveness in rural operations is exceptional, that keep tactical operations as safe as possible." As a result of the surveillance, the SWAT team stormed in and arrested Brossart and others without incident.

Brossart's attorney, Bruce Quick, argues that the use of the drone was unlawful on Fourth Amendment grounds. He points to the United States Supreme Court holding in the case of Kyllo v. United States ( 533 U.S. 27, 2001), in which the Court held that obtaining information by sense-enhanced technology not available for use by the general public will be subject to constitutional protections against unreasonable searches and seizures.

John Villasenor, an expert on information gathering and drone use with the Washington, D.C. based Brookings Institution points to two other Supreme Court cases - California v. Ciraolo in 1996 and Florida v. Riley (488 U.S, 445, 1989) - that allow law enforcement to use "public navigable airspace, in a physically nonintrusive manner" to gather information to make an arrest.

As an aside, the government began issuing permits for drone use by law enforcement agencies on May 14, 2012. Currently, about 300 law enforcement agencies and research institutions have "temporary licenses" from the FAA to use drones (Including the Grand Forks SWAT team).

\section{DISCUSSION QUESTIONS}

1. Decide the case under the law; support your verdict with arguments and show the weakness (if any) in your decision.

2. Write a decision. Imagine that you have taken an oath to follow the law.

3. Hold a discussion in which your group considers the holdings in the following cases:

a. Minnesota v. Olson - 495 U.S. 91 (1990)

b. Hicks v. State - Court of Appeals of Georgia, \#A07A1796, August 03, 2007

c. Maryland v. Buie - 494 U.S. 325 (1990)

d. United States v.Robinson - 414 U.S. 218 (1973)

e. Chimel v. California - 395 U.S. 752 (1969)

f. Steagald v. United States, 451 U.S. 204 (1981)

g. California v. Ciraolo - 476 U.S. 207 (1986)

4. Be certain to address the issues presented in Kyllo v. U.S, 533 U.S. 27 (2001), as well as Florida v. Riley, 488 U.S. 445 (1989).

\section{AUTHOR INFORMATION}

Benjamin A. Neil serves as a Full Professor of Legal Studies at Towson University, located in Towson, Maryland. $\mathrm{He}$ is the author of numerous Journal articles in the legal studies field. E-mail: Bneil@towson.edu (Corresponding author)

Benjamin A. Neil II serves as an Adjunct Professor of Homeland Security in the Master's Program at Towson University, located in Towson, Maryland. He has authored several related Journal articles. 


\section{TEACHING NOTES}

1. Decide the case under the law; support your verdict with arguments and show the weakness (if any) in your decision.

In this case, the man chased the police off of his property with guns that were more likely larger and more powerful than any the police had on them when they came to the home. The owner of the property decided to make the police stand there for 16 hours as they waited for him to either give up or fight. It was not until the drone was used that the police were able to go in and make an arrest and do it safely. Without the technology I am not sure that the standoff would not have lasted longer and that there would have been a greater possibility of injury.

There may have been some argument if the police did not have a warrant, but they did. And since they did, I do not see why they were not able to use the drone. Just as they could have used a helicopter or other kind of plane if they had those resources available to them at the time.

2. Write a decision. Imagine that you have taken an oath to follow the law.

Obviously there are many reasons to be given why using this type of technology on the citizens of this nation is wrong and probably not close to Constitutional in many instances. In this one, however, I am not sure. The man chased the police off his property with guns that were more than likely larger than any the police had on them when they came to the home. The owner of the property decided to make the police stand there for 16 hours as they waited for him to either give up or bring the fight to the police. It was not until the drone was used that the police were able to go in and make an arrest and do it safely. Without the technology I am not so sure that the standoff would not have lasted another day or so, maybe even longer and there would have been a great possibility of injury the longer it went on.

Looking at this from a legal angle, I am not so sure that court is not going to rule on the side of the police, even if this does make its way all the way up to the U.S. Supreme Court. There may have been an argument if the police did not have a warrant for the property, but since they did, I do not see why they would not be able to use this drone like they could have used a helicopter or other kind of plane if they had those resources available to them at the time.

Just because this is the first case and there is no precedent to look at does not mean that somewhere down the road situations could change and the drone be used on someone that it should never have been used on. In that case, we need to keep our eyes and ears open to the possibility of abuse in the future.

3. Hold a discussion in which your group considers the holdings in the following cases:

\section{a. Minnesota v. Olson}

Police suspected respondent Olson of being the driver of the getaway car used in a robbery-murder. After recovering the murder weapon and arresting the suspected murderer, they surrounded the home of two women with whom they believed Olson had been staying. When police telephoned the home and told one of the women that Olson should come out, a male voice was heard saying "tell them I left." Without seeking permission, and with weapons drawn, they entered the home, found Olson hiding in a closet and arrested him. Shortly thereafter, he made an inculpatory statement, which the trial court refused to suppress. He was convicted of murder, armed robbery and assault. The Minnesota Supreme Court reversed, ruling that Olson had a sufficient interest in the women's home to challenge the legality of his warrantless arrest that the arrest was illegal because there were no exigent circumstances to justify warrantless entry, and that the statement was tainted, and should have been suppressed.

Held: The arrest violated Olson's Fourth Amendment rights. 


\section{b. Hicks v. State}

Following a jury trial, Ernest Hicks appeals his conviction for possessing a firearm while a convicted felon. His sole enumeration is that the trial court erred in denying his motion to suppress certain evidence found in a warrantless search of his home. We agreed that under the Fourth Amendment, no exigent circumstances justified the police's warrantless search of Hick's entire residence after they had handcuffed him and placed him outside the residence under the watchful eye of an officer. Their failure to obtain a warrant invalidates the subsequent search and compels us to reverse his conviction, which was obtained based on the discovery of a shotgun under his bed during the search. The case is remained for a new trial, in which the illegally obtained evidence may not be introduced.

\section{c. Maryland v, Buie}

The Fourth Amendment permits a properly limited protective sweep in conjunction with an in-home arrest when the searching officer posses a reasonable belief based on specific and articulable facts that the area to be swept harbors an individual posing a danger to those on the arrest scene. Court of Appeals of Maryland vacated and remanded.

\section{d. United States v. Robinson}

In the case of a lawful custodial arrest, a full search of the person is not only an exception to the warrant requirement of the Fourth Amendment, but is also a "reasonable" search under the Amendment.

\section{e. Chimel v. California}

An arresting officer may search only the area "within the immediate control" of the person arrested, meaning the area from which he might gain possession of a weapon or destructible evidence. Any other search of the surrounding area requires a search warrant.

\section{f. $\quad$ Steagald v. United States}

Pursuant to an arrest warrant for Lyons, Drug Enforcement Administration agents entered petitioner's home to search for Lyons without first obtaining a search warrant. In the course of searching the home, the agents found cocaine and other incriminating evidence, but did not find Lyons. Petitioner was then arrested and indicted on federal drug charges. His pretrial motion to suppress all evidence uncovered during the search of his home on the ground that it was illegally obtained because the agents failed to obtain a search warrant was denied by the District Court, and petitioner was convicted.

A search warrant requirement, under the circumstances of this case, will not significantly impede effective law enforcement efforts. An arrest warrant alone suffices to enter a suspect's own residence, and, if probable cause exists, no warrant is required to apprehend a suspected felon in a public place. Moreover, the exigent circumstances doctrine significantly limits the situations in which a search warrant is needed. And in those situations in which a search warrant is necessary, the inconvenience incurred by the police is generally insignificant. In any event, whatever practical problems there are in requiring a search warrant in cases such as this, they cannot outweigh the constitutional interest at stake in protecting the right of presumptively innocent people to be secure in their home from unjustified forcible intrusions by the government.

\section{REVERSED AND REMANDED}

\section{g. California v. Ciraolo}

California v. Ciraolo held that "The Fourth Amendment simply does not require the police traveling the public airways \{at this altitude\} to obtain a warrant in order to observe what is visible to the naked eye." 
The Court also stated that "respondent's expectation of privacy from all observations of his backyard was unreasonable. That the backyard and its crops were within the "curtilage" of the respondent's home did not itself bar all police observation. The mere fact that an individual has taken measures to restrict some views of his activities does not preclude an officer's observation from a public vantage point where he has a right to be and which renders the activities clearly visible.

4. Be certain to address the issues presented in Kyllo v. U.S, 533 U.S. 27 (2001), as well as Florida v. Riley, 488 U.S. 445 (1989).

Kyllo v. United States held that the use of a thermal imaging device from a public vantage point to monitor the radiation of heat from a person's home was a "search" within the meaning of the Fourth Amendment and thus required a warrant. Because the police in Kyllo did not have a warrant, the Court reversed Kyllo's conviction for growing marijuana.

Not the case here. This case did not involve a "search" inside the home. Therefore, it did not violate any expectation of privacy by the defendant. And the police did have a warrant in our case.

Florida v. Riley held that police officials do not need a warrant to observe an individual's property from public airspace.

The Supreme Court reversed the decision of the Florida Supreme Court, arguing that the accused did not have a reasonable expectation that the greenhouse was protected from aerial view, and thus that the helicopter surveillance did not constitute a search under the Fourth Amendment.

The Court's ruling also maintained that the helicopter did not interfere with the normal use of the property: "As far as this record reveals, no intimate details connected with the use of the home or cartilage were observed, and there was no undue noise, no wind, no dust, or threat of injury. In these circumstances, there was no violation of the Fourth Amendment." 


\section{NOTES}

